\title{
Power Sharing as a Tool for Resolving Electoral Violence: Revisiting the Zimbabwean Experience
}

\author{
Happy Mathew Tirivangasi and Louis Nyahunda*
}

\author{
Department of Research Administration and Development, University of Limpopo, P. bag X1106, Sovenga, \\ 0727, South Africa
}

\begin{abstract}
This paper uses Hartzell and Hoddie's four dimensions of power-sharing to analyse the implementation of the 2008 power-sharing in Zimbabwe and its impact on electoral violence. It interrogates the resolving of the Zimbabwean electoral violence through the use of power-sharing deal between the opposition and the ruling party. The theoretical explanations why electoral violence would occur in a country ruled by an authoritarian leadership suggests that, autocratic governments use electoral violence as a way of influencing the electoral outcome. The other position suggests that the weaker political party is the one responsible for electoral violence as it enjoys the monopoly of being the victim. This study dispels the notion that power-sharing has any impact on resolving electoral violence permanently, we argue that the resolving election dispute through power-sharing does not resolve the differences between warring parties rather, it gives temporary peace. The findings of this study support the position of the electoral authoritarian theoretical perspective that autocratic government will use violence and all the means necessary to ensure that they return the power.
\end{abstract}

Keywords: Power-sharing, Electoral Violence, Authoritarianism, Democracy, Zimbabwe.

\section{INTRODUCTION}

The history of power-sharing in Zimbabwe is not a new phenomenon as noted by Penu and Vandeginste (2018), the country had such political arrangement in 1978. The first government of national unity was formed between lan Smith and the other three African leaders led by Abel Muzorewa (Chigora \& Guzura, 2011). The aim of the power sharing was to end the guerrilla war and Smith wanted to serve the white minority interest as well as safeguarding his suppressive rule. They held internal elections which were won by Muzorewa's party United African Nationalist Congress (UANC). The power-sharing was short-lived as it hardly consisted of all key players. After the historic elections won by Zimbabwe African Nationalist Union People's Front (ZANU PF), ZANU PF won the majority seats but still entered into the unity government with PF ZAPU and the Rhodesian Front (Chigora \& Guzura, 2011). This power-sharing exhibited some sort of consociational power-sharing arrangement, as it ensured representation of all ethnic groups. The formation of a power-sharing arrangement was in line with the Geneva Conference of 1976, which encouraged parties emerging from conflict to work as one. ZANU PF gave PF ZAPU, only five cabinet posts out of a total of thirty-six cabinet posts (Laakso, 2003).

However, this inclusive government was short-lived because in 1982, ZANU PF accused PF ZAPU of plotting a coup as the government security agencies

*Address correspondence to this author at the University of Limpopo, South Africa; Tel: +27 15268 2401; E-mail: nyahundalouis@gmail.com claimed to have found weapons on a plot owned by PF ZAPU. Robert Mugabe pushed for a one-party state since the country's independence and this meant the suppression of the main opposition threat which at the time was, PF ZIPRA (Kriger 2005). This was achieved after ZANU PF orchestrated the mass killings of the main leaders of PF ZIPRA and many of its supporters who were mainly from the Ndebele tribe (Sithole \& Makumbe, 1997). The killing of the PF ZAPU supporters during the first six months of 1985 weakened the party during the 1985 elections. According to Kriger (2005) violence occurred prior to elections during the gukurahundi period where an estimated 20000 Ndebele people were killed by the North Korean trained $5^{\text {th }}$ brigade military regiment which existed outside the main army. The leader of PF ZIPRA was forced to join the Unity government in 1986. This became the second power sharing deal in Zimbabwe. The power-sharing in 1986 guaranteed PF ZIPRA, the position of a vice President in each government formed by ZANU PF until recently with the ouster of Robert Mugabe where such agreemen is now null (Ndlovu-Gatsheni 2009). In the aftermath of the 1986 unity government, the main opposition PF ZAPU was dismantled and Mugabe's envisioned one party state became a reality.

Based on the narrative above, studies on Zimbabwe have revealed that ZANU PF has used electoral violence to maintain its grip on power and influence voter's behaviour (Rich 1982; Tevera 1989; Laakso 1999; Makumbe \& Compagnon 2000; Masunungure 2009). This led to the contested 2008 elections which ZANU PF lost to Tsvangirai and the MDC T but used its 
coercive power to maintain power. The party utilised state affiliated agencies to inflict violence on the opposition in areas they performed badly. The operation become popularly known as operation makavhoterapapi (who did you vote for) and reports of people being maimed and killed became common (Ndlovu-Gatsheni, 2012). This discredited the elections and rendered elections useless as a way of exchanging power (Ndlovu-Gatsheni 2009; Ndlovu-Gatsheni and Muzondidya 2011). With the crisis escalating the Africa Union and Southern African Development Community (SADC) intervened resulting in the third power-sharing government formed in the country. The Global Political Agreement (GPA) of 15 September 2008 which witnessed the formation of an inclusive government in February 2009.

Studies from many scholars have shown an increase in power-sharing deals on the African continent with countries such as Sudan, Chad, Liberia, South Africa, Central African Republic, Djibouti, Comoros Island, Angola, Mali, Somalia, Congo, DRC and Senegal adopting it (Mitchell, 2012). Looking at the countries mentioned above by Mitchel, power-sharing was utilised in order to terminate war or resolve the conflict between ethnic groups. The study by Mehler (2009) reveal that only Kenya, Madagascar and Zimbabwe have implemented power-sharing as a result of political crisis (election disputed) rather than civil war. The preliminary literature analysis on these few case studies show that there are few studies which investigated the implementation of power-sharing after electoral violence with reference to a theory. This is with the exception of Finkeldey (2011) who applied Lijphart's consociationalism theory to the case of Zimbabwe. To fill this wider gap left in literature, this paper seeks to analyse the implementation of the 2008 power-sharing deal in Zimbabwe and its impact on electoral violence using the four dimensions by Hartzell and Hoodie (2003), namely political, military, economic and territorial dimensions. To attain this goal, this study grapples with the following questions: What did the power-sharing deal look like in Zimbabwe? Secondly, what is the impact of power-sharing deal on electoral violence?

\section{REVIEW OF LITERATURE}

\section{Why Power-Sharing?}

In most common instances, power sharing has been implemented in order to end war. This was achieved by bringing together the warring groups to the table for discussions with peace as the objective. This is the most common reason for power sharing to resolve power issues for countries emerging from conflict as seen in Democratic Republic of Congo, Burundi and Sudan. There are many reasons why power sharing deals were adopted in different countries and the types of power sharing differed. For instance, according to Vandeginste (2009), Burundi implemented a power sharing deal which assumes more of consociational democracy characteristics. A model developed by Arend Lijphart, which resolve power distribution for states emerging from conflict. This is usually applied in ethnically divided societies, where even a minority group will have veto powers in deciding important decisions (Shale, 2010). The consociational approach would ensure that all parties are represented. This type power sharing makes everyone happy and promotes morale and sense of patriotism as it brings the much sought-after peace and paves a path to democratic future, for instance in the case of South Africa.

Matlosa and Shale (2013) writing on power sharing arrangements in Africa noted that at the end of cold war in 1989, the introduction of multiparty elections in Africa between 1990 and 2000 was a cause for great excitement. This was viewed as a good move and the idea of having electoral competition was celebrated. Elections themselves do not equal to democracy since it would involve other aspects such as constitutional, legal frameworks, institutional, historical, socioeconomic, political and cultural factors, but they represent the flagship of democracy (Matlosa \& Shale, 2013). Scholars like Fukuyama celebrated the defeat of Russia as the victory for democracy and Lindberg (2008) argued that as nations continue holding democratic elections, the closer they are transformed into democratic states. However, what the democratic supporters and institutions of democracy forgot was that multi party elections only work when the power of the non octogenarian leaders is not threatened. The celebration of electoral competition only without interrogating the conditions or quality of the conditions in which these elections are hosted results in severe consequences. The incumbent leaders exerted violence to preserve their power. In order to resolve the impasse over election results, power sharing was opted for, thus postponing the total removal of holding elections but bringing peace and inclusivity of all parties in sharing the power. Instead of having one party assuming power through violence, power is shared among all parties involved through consociationalism or another form of power sharing. 
However, this only served to confirm the observation made by Kanyinga, Okello and Akech (2010:321) who noted that during elections "one of the problems we are faced with in Africa is that many leaders seem to think the issue is not voters choosing leaders, but rather leaders choosing voters". During the power sharing, the power of choosing leaders is no longer resting with the electorate but with the politicians themselves as they scramble for positions.

The second type of power sharing occurred in Kenya and Zimbabwe. This was done to resolve power issues emanating from election disputes. This form of power sharing that occurs after the elections and not before. It is implemented in order to prevent the further loss of life. In Kenya, violence occurred between Odinga's supporters and Kibaki's supporters. This resulted in the death of at least 1000 people (Baldauf, 2008). The power sharing deal was broken by Kofi Anan, the former United Nations secretary general and resulted in both parties forming a new government and bringing an end to the killings. The motive of the power sharing in Kenya is more similar to the case of Zimbabwe which is under discussion in this paper. With the help of SADC, ZANU PF and the opposition parties shared power and this resulted in the end of persecution of the opposition members.

According to Cheeseman and Tendi (2010), power sharing would provide a better option for pursuing peace and resolving conflict than all other mechanisms. The first notable reason as provided by other previous studies noted by the two scholars is that, power sharing brings the warring groups together to form a government and this would result in a more inclusive government. Secondly, the government of national unity brings some legitimacy to the government ruling and this contrasts with a situation where a party self declares its victory. The last factor although contested by this paper is a fact that power sharing results in the development of institutions which would ensure democracy. The effectiveness or assumed stability brought by the power sharing in Africa has resulted in other countries such as Sudan, Chad, Liberia, South Africa, Central African Republic, Djibouti, Comoros Island, Angola, Mali, Somalia, Congo, Democratic Republic of Congo (DRC) and Senegal adopting such approach (Mitchell, 2012). The inclusiveness, legitimacy, end to violence and hope for institutional reforms are the common features why power sharing would occur despite the conditions involved.

\section{THEORETICAL UNDERPINNINGS OF THE STUDY}

This study adopted the theoretical model by Hartzell and Hoddie's (2003) to analyse the success and failure of the Zimbabwean power sharing. We consider this model to be very comprehensive and important as Hoddie and Hartzell's four dimensions namely, political, territorial, military and economic touch important aspects of power sharing. The political dimension describes how power is shared among the political parties and the elite players. The scholars limited the scope of power sharing to electoral proportional representation, administrative proportional representation, and executive proportional representation. The second dimension is territorial, which refers to federalism or regional autonomy (Hartzell \& Hoddie, 2003). The military dimension this involves the distribution of the coercive power (Hartzell \& Hoddie, 2003). In other scenarios it would imply, bringing together the warring forces together. The economic dimension involves the distribution of economic resources among the parties. In this study, I recognise the limits of this model when applied to postelection power sharing however, it is the one that comes close to explaining the dynamics involved. Alternately, studies of Lijphart (1977) and Nordlinger (1972) have also investigated and came up with some forms of power sharing which can be implemented in countries emerging from conflict. These studies provided a ground breaking pathway to how warring sides can share power. However, we adopt a more narrowed down or simplified way of analysing power sharing where power is viewed from the four dimensions mentioned by Likphart's theory rather than seeing power from the political lenses which investigates grand coalitions, understandings of proportional representation and proportional representation.

\section{RESEARCH METHODOLOGY}

This is a qualitative desktop study. We used Hoddie and Hartzell's theoretical model of power-sharing's four dimensions to analyse the implementation power sharing deal in Zimbabwe and its effect on electoral violence. Data was collected between March and April 2019, we utilised the web of science, google scholar data bases, ScienceDirect, University of Antwerp institutional repository to access articles in the field of conflict studies, democracy, governance, and electoral studies referencing electoral violence and power sharing. Table 1 shows the key words or terms used to identify information. 
Table 1: The Search Items: Key Words and Phrases

\begin{tabular}{|c|}
\hline Search terms \\
\hline \hline Power sharing in Zimbabwe \\
Electoral violence \\
Economic performance \\
2013 Zimbabwe elections \\
2018 elections and violence \\
Prospects of power sharing in 2018 elections in Zimbabwe \\
Implementation of the power sharing deal: \\
Power sharing in Zimbabwe: Weaknesses and prospects \\
\hline
\end{tabular}

Source: Authors.

As reflected in Table 1, we used the search items/ the key words and phrases to identify articles. The search returned an approximate 189 hits and we further checked and screened for relevance. Furthermore, bibliographies and reference list of the important contributions from (Hartzel \& Hoddie, 2003; Vandeginste, 2009; Mehler, 2009; Cheeseman \&Tendi, 2010; Noyes, 2013; Chitiyo \& Kible, 2014; Aeby, 2018 etc), were used to identify further relevant scholarly papers for this publication. Further sources from Afrobarometre, reports from election observers, books, policy review papers, newspapers and journal articles were utilised. Lastly documentary analysis of the text was found in order to find meaning and develop sound argumentation.

\section{RESULTS AND DISCUSSION}

This section presents the results and discussion from the analysis done:

\section{Implementation of the Power-Sharing Deal: Weaknesses and Prospects}

With regards to the four dimensions presented by Hartzel and Hoddie's theoretical model of powersharing not all dimensions are directly applicable to the context of Zimbabwe, Kenya and Madagascar. This is due to the fact that available theories were designed to analyse post civil war settlements and the researchers had not anticipated power sharing settlements due to political crisis or electoral violence. Despite such weakness, this study builds itself on Hartzel and Hoddie's four dimensions to reveal the implementation as well as reveal the existing relationships between these dimensions in the case of Zimbabwe. The study findings are discussed under political, military, economic and territorial dimension. The last section discusses the impact of power sharing on electoral violence.
The political dimension shows how power is distributed among the political parties. Hartzel and Hoddie (2015, p.41) note that "Political power sharing emphasizes proportionality in the distribution of central state authority." In the context of Zimbabwe, political power was shared among the three main political parties namely, Movement for Democratic ChangeTsvangirai (MDC-T), MDC-Mutambara (MDC-M) and ZANU PF. In this agreement, which was signed on September 15 2008, Robert Gabriel Mugabe became the President, losing to Tsvangirai in the general presidential elections; the late Morgan Tsvangirai became the Prime Minister, Prof. Arthur Mutambara and Thokhozani Khupe became the Deputy Prime Ministers. The power sharing deal at least from the perspective of the western governments and the civil society was supposed to curb the power Robert Mugabe, who had ruled the country since its independence. However, according to the study by Hoekman (2013), the opposition was outsmarted by ZANU PF and SADC during the talks as Mugabe retained his executive powers and all-important ministries except for the finance ministry. The two MDC formations got 16 cabinet posts and ZANU PF got 15 cabinet positions (Mutisi, 2011).

This was clearly antagonistic to the initial intentions of the power sharing deal which seeks to share power rather than just to accommodate the opposition. Hartzel and Hoddie (2003) sees that the goal of the power sharing is to make sure that no political player would have significant power which they fail to secure on the battlefield and further, the power of political stakeholder should not threaten the existence of the other within the government. In this political arrangement, Mugabe and his party were left with significant power which blocked some reforms because his power was not reduced but was only maintained. The consequence of Mugabe and ZANU PF returning the key government ministries and executive power is clearly summed up by various scholars when they note that, as long the incumbent leader is having power to choose or block appointments, no significant change would transpire (Mehler, 2009; Cheeseman \& Tendi, 2010; Mitchel, 2012). This would justify the sentiment that power sharing for ZANU PF was a marriage of convenience. Miti, Abatan and Minou (2013) observed that the incumbent government would refuse defeat in order to remain in power through the government of national unity.

The military dimension, according to Hartzel and Hoddie (2003), determines who gets the coercive 
power. Hartzel and Hoddie (2015, p.41) note that "The most straightforward means of sharing military power is integrating the antagonists' armed forces into a unified state security force". This is most functional when trying to distribute the coercive state apparatus by ensuring that none of the parties loses the control of their soldiers when coming from a civil war (Hartzel \& Hoddie, 2003). The equal integration of the armed forces like in the case of Burundi would ensure that neither of the parties is at a disadvantage. However, even though the theory of Hartzel and Hoddie tries to resolve the military power question, the scholars did not anticipate a situation where power sharing comes as a result of electoral dispute. In this case it would mean that one party has control over security forces which include the control of army, the police and secret police. The absence of a civil war conflict made the SADC mediators to overlook the military dimension.

However, this is one critical dimension forgotten by SADC mediators as the study by Hartzel and Hoddie (2003) would reflects that power sharing needs to address military dimension inorder to have lasting peace. This is in line with the objective of power sharing as advanced as the two scholars when they state that power sharing is enforced to answer questions like who will control the state institutions like military coercive power? Undrestanding such questions would make one emerge with a good power sharing deal. In the absence of civil war conditions where each party has its soldiers to integrate with the other, questions of security sector reform should be raised.

In the case of Zimbabwe, the army and security sector were not apolitical like in the case of Kenya. The army maintaining a veto power on the proceeding of the power sharing as well as the performance of the government of national unity (Cheeseman \& Tendi, 2010). The existence of unequal balance of power in regard to the use of state apparatus such military would render the opposition weak to execute or perform its duties. Mehler (2009) also found this intriguing and the author takes an excerpt from the interview conducted by Cheeseman and Tendi with the former deputy prime minister Arthur Mutambara who was quoted saying "you can see that we are not in full control. We are not exactly in charge. There are other forces in control" (Mehler, 2009: 6).

The blurred lines between ZANU PF and the army are clearly shown prior to the 2008 elections. The head of the prisons which is part of the Zimbabwe Defense forces said, "I will only support the leadership of Robert
Mugabe" (Mail \& Guardian, 2008:1). On another occasion, the retired general said:

"If the opposition wins the election, I will be the first one to resign from my job and go back to defend my piece of land. I will not let it go. "We are going to the elections and you should vote for President Mugabe," (AllAfrica, 2008:1).

Sachikonye (2011) noted that patronage had deepened between ZANU PF and the service chiefs. The securocrats had accumulated wealth and that made them to want ZANU PF to remain in power than the party members themselves by openly declaring that they will not accept the power gained through electoral process. As noted below:

\section{"Available evidence suggests that the regime came to the conclusion that its party had failed in the march to 29 March and therefore the military should lead the march to 27 June" (Masungure, 2011:80).}

The mere fact that the military had been used to coerce voters during the runoff which led to the power sharing deal shows the extent to which the military factor should not have been ignored during the negotiations and implementations of post electoral violence power sharing settlements.

According to Hartzel and Hoddie (2003), the economic dimension involves the distribution of the economic resources among the political parties. The scholars argue that when the political parties lose the elections, it also means that they have lost access to resources of the state which they previously used to maintain loyalty of their members. Hence consequently, the economic power sharing would have sought to allocate "wealth, income, or control of natural resources or production facilities" (Hartzel \& Hoddie, 2015: 42). In the Zimbabwean power sharing deal, ZANU PF took all the powerful ministries except for the finance ministry which went to MDC $T$. The party compensated itself by taking the ministry of Mines and mineral development which had access to diamonds mines (Saunders, 2010). The main beneficiaries of the diamond extraction were the Zimbabwe National Army (Saunders, 2014). As noted by Biti (2015, p.2), when MDC T took over the Ministry of Finance in 2009 the inflation stood at 500 billion. This summed up the economic hardships that the Zimbabweans were encountering. Hence, transferring the Ministry of 
Finance to the opposition was not deemed as a loss by ZANU PF.

Cheeseman and Tendi (2010) argue that giving MDC $T$ the Finance ministry was a strategic move to syphon money from international aid through the MDC links to the western donors. This could not be far from truth as the economy and inflation stabilised within a short space of time. The Finance ministry headed by Tendai Biti crafted and implemented the Shortened Emergency Recovery Program (STERP). As a result, by 2013 monthly inflation was less than $4 \%$ (Biti, 2015). Zimbabweans remember this period fondly as it represented hope and economic stability last witnessed in a long time. In this regard, I can credit economic power sharing as a good initiative as it brings stability to the economy. However, we can not ignore the fact that it also incentivises the incumbent leader with other things. In this case, ZANU PF with the help of the stability of the economy during this period utilised the money accessed from diamonds to revitalise itself.

According to Hartzel and Hoddie (2015, p. 42), territorial dimension "seeks to divide political influence among different levels of government by creating forms of decentralized government that are territorially based." This simply means giving autonomy or power to regionally concentrated groups such that they can act independently from the central government. Zimbabwe is divided into two main ethnic groups namely, the Ndebele and the Shona. ZANU PF enjoys the support mainly from the Shona tribe and both MDC formations enjoy a significant support from both Shona and the Ndebele tribes. In this regard under Mugabe administration, the Ndebele people were isolated and suffered at the hands of ZANU PF. The Ndebele people were the first to suffer pre-electoral violence during the gukurahundi period in 1985 and they have not been allowed to exhume the mass burials which occurred during the time, nor did a proper transitional justice discussion regarding the matter occur (Cheeseman \& Tendi, 2010; Dziva, Dube \& Manatsa, 2013; Robben, 2018). This dilemma between power sharing and transitional justice is well illustrated by the work of Vandeginste and Sriram who note that there is "potential for conflict between a provision of territorial autonomy and the pursuit of transitional justice" (Vandeginste \& Sriram, 2011: 497).

So, this is true, despite the existence of such a need for transitional justice issues to be addressed. The power sharing deal in Zimbabwe did not grant the autonomy to either parties or the groups affected by the past atrocities committed ZANU PF during the past elections. This is further exhibited when the minister of National Healing and Reconciliation, Moses MzilaNdlovu was arrested for overseeing a memorial service for the gukurahundi victims in Matabeleland and Midlands provinces (Voice of America, 2011).

\section{The Effect of Power-Sharing on Electoral Violence in Zimbabwe}

The previous section has revealed the context and the implementation of the power sharing deal. The impact of power sharing can be assessed by the actions taken to prevent the occurrence of electoral violence during election, this can be institutional reforms or lack of thereof. I used the 2013 and 2018 elections as my case studies to draw positives and negatives of the power sharing deal. I will start by revealing the perception of the general public in

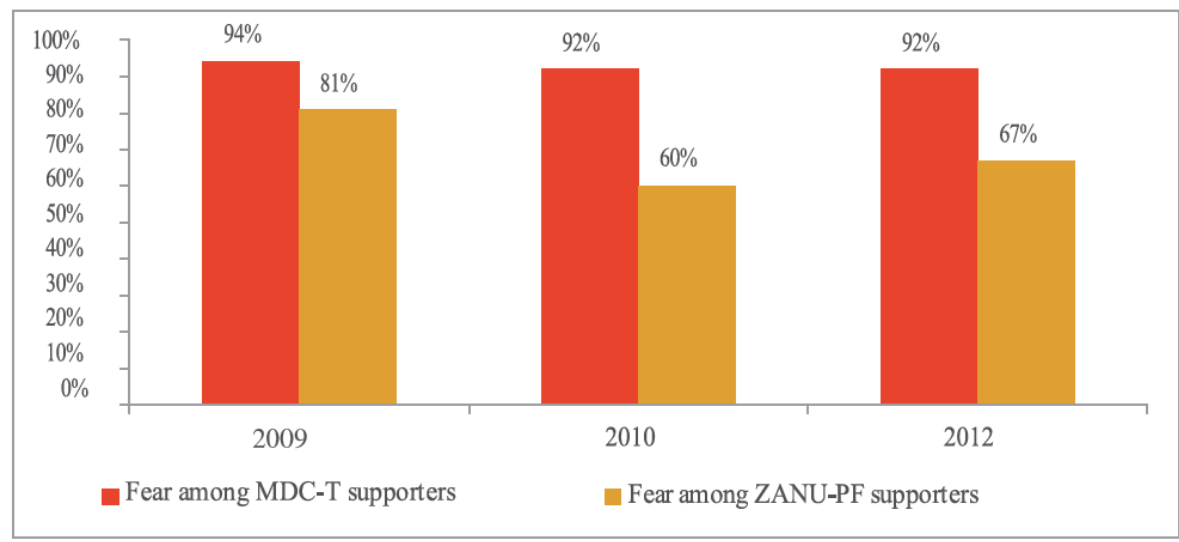

(\% who feared political intimidation or violence "a lot," "somewhat," or "a little bit")

Figure 1: Fear of political intimidation or violence and voting intentions: Zimbabwe- 2009-2012.

Source: Ndoma, 2015:3). 
Zimbabwe regarding the use of violence in a country study done by Afrobarometre between 2011 and 2013 are shown in Figure 1, reveals Zimbabweans are afraid of electoral violence since the 2008 elections to the period leading to the 2013 elections.

This preliminary results from the Afrobarometre motivates the researchers to delve in the shortcomings of the power sharing deal of the government of national unity in resolving electoral violence. As indicated under the political power dimension, during the allocation, MDC formations did not get enough power to effect reforms in the government to ensure violence does not occur again. The powerlessness of MDC formation is noted by the failure of the GNU in appointing the agreed governors and a fair attorney general (NdlovuGatsheni, 2012). This is reflected by the early signs noted by McGreal (2009) when Mugabe refused to release $\mathrm{MDC}$ activists up to the point when the deal was signed. This is evidence that ZANU PF lacked sincerity in the whole process. It can easily resort to the violence means and this justifies the finding by the Afrobarometre in Ndoma (2015) which show that, a higher percentage of Zimbabweans are afraid of electoral violence and intimidation.

The second aspect is the lack of agreement on how to do military reform after the signing of the power sharing deal and this presents a challenge for the future of Zimbabwe elections as the literature findings of this study show that the securocrats were on the forefront in coercing and exerting violence during the presidential runoff in 2008. The error was leaving such a powerful actor from the talks as these security agents are not apolitical. Mandaza (2011), a renowned scholar on Zimbabwean politics noted that the securocrats were like the war lords, inventors of violence. Mandaza argues that ZANU PF has been captured by the securocrats. This group of defence and police generals regarded themselves as the vanguards of the liberation party ZANU PF (Ndlovu-Gatsheni, 2012).

Mandaza (2011) argues that there is no way that elections in Zimbabwe would occur with no violence as the securocrats elections represent a battlefield where their interest is at stake. The observations of these two scholars were soon to be realised prior to 2018 elections as the military removed Mugabe in a military coup like action. Instead of being on the side-lines on the current dispensation, the securocrats took positions of power in the government with the former Army Commander under Mugabe, Constantino Chiwenga becoming the Vice President; the ministry of land was headed by the late Perence Shiri, former Air Force Army General and the Ministry of Foreign Affairs was headed by the late Major General Sibusiso Moyo (BBC, 2017). This contrasts with the will of the Zimbabwean people, according to Afrobarometre (2019) survey conducted during the $2016-2018$ round 7 in Zimbabwe, the majority of the $69 \%$ of the people interviewed disapprove of military rule. The country wide people's perceptions are shown below in Table 2.

\section{Table 2: Perception of on Whether One would Approve or Disapprove Military Rule: 2016/2018 (Zimbabwe)}

\begin{tabular}{|c|c|c|}
\hline Category & $\% /$ Total & Frequence \\
\hline \hline Strongly Disapprove & $43.0 \%$ & 515 \\
\hline Disapprove & $25.7 \%$ & 309 \\
\hline Neither Approve Nor Disapprove & $6.4 \%$ & 77 \\
\hline Approve & $13.9 \%$ & 167 \\
\hline Strongly Approve & $5.6 \%$ & 68 \\
\hline Refused & $0.9 \%$ & 11 \\
\hline Don't know & $4.4 \%$ & 53 \\
\hline$(\mathrm{N})$ & $(100 \%)$ & $(1,200)$ \\
\hline
\end{tabular}

Source: (Afrobarometer, 2019).

Although, the world was deceived into accepting a coup d'etat in Zimbabwe in order to get rid of Mugabe, they just reinforced the military rule in Zimbabwe. The evidence of the true perpetrators of violence in Zimbabwe was reflected in the aftermath of the 2018 elections, as the military unleashed soldiers on unsuspecting protesters from MDC T who felt that their votes were stolen. The military opened fire on the demonstrators killing 6 people and injuring many others. Unlike the assertion of the small party theory, which alludes that when opposition loses election, it would unleash violence, in this case, the opposition actually won, the situation in Zimbabwe reinforced the authoritarian electoral violence theory by (Chaturved, 2005; Schedler, 2006; Bhasin \& Ghandi, 2013; Taylor, Pevehouse \& Straus, 2017). which state that the incumbent leader would engage in violence to maintain power at all costs.

Despite power sharing, the literature continues to reveal that most of violent acts are perpetrated by ZANU PF and its security apparatus as indicated by the research carried our Research and Advocacy Unit (RAU) in Table 3 below:

These results are also supported by the findings of Freedom House (2019) on Zimbabwe. The study 
Table 3: Frequency of Actors against Events in Zimbabwe, 1998 to 2018

\begin{tabular}{|c|c|c|}
\hline & Number of events & $\%$ of total \\
\hline Zimbabwe Republic Police & 846 & 14,4 \\
\hline Militia & 97 & 1,7 \\
\hline War Verts & 234 & 4,0 \\
\hline ZANU PF & 2607 & 44,5 \\
\hline Zimbabwe National Army & 397 & 6,7 \\
\hline Central intelligence Organisation & 91 & 1,6 \\
\hline MDC & 241 & 4,1 \\
\hline Protesters & 666 & 11,4 \\
\hline Rioters & 321 & 5,5 \\
\hline Others & 364 & 6,2 \\
\hline
\end{tabular}

Source: (RAU, 2018, p.4).

results reveal that there is no freedom of assembly in the country as the country scored 1 out of 4 on the index. The police use a section of the constitution POSA to approve, prohibit or impose penalties on demonstrators. In 2018 post election, the army injured hundreds of demonstrators. The security forces and ZANU PF perpetrators enjoy impunity offered by the state. The study findings can clearly show that the 2008 power sharing deal did not end electoral violence.

\section{CONCLUSION}

In a nutshell, the tentative findings of this study reveal that it is important to understand the context to which power sharing deal is applied. In every power sharing deal, it is important to understand the key players involved, thus enables the mediators not to leave out important stakeholders. In the case of Zimbabwe, leaving the service chiefs was a grave error as they are a great influence in Zimbabwean politics and threatened the very existence of power sharing and weakened the MDC parties' position. Yet power sharing presents an opportunity to end violence and make the process towards democratisation, it is imperative to put accountability and transparency measures that ensure that the opposition has the veto power to make reforms happen. The power sharing deal in the case of Zimbabwe helped to stabilise the economy in the short period yet on the negative side, it rescued ZANU PF from collapse, revitalised and strengthened Mugabe's rule.

\section{REFERENCES}

Aeby, M. (2018). Inside the Inclusive Government: Interparty Dynamics in Zimbabwe's Power-Sharing Executive. Journal of Southern African Studies, 44(5), 855-877.

https://doi.org/10.1080/03057070.2018.1497122
Afrobarometre. (2019). Afrobarometer R7 2016/2018 (Zimbabwe). Retrieved from: https://afrobarometer.org/online-dataanalysis/analyse-online.

AllAfrica. (2008). Zimbabwe: I'll Not Salute Tsvangirai, Makoni - Defence Chief. Retrieved from: https://allafrica.com/stories/ 200802290099.html.

Baldauf, S. (2008). After two months of discord, finally a handshake. The Christian Science Monitor, 8 August 2008.

BBC. (2017). Zimbabwe's Mnangagwa gives key cabinet jobs to military figures. Retrieved from: https://www.bbc.com/news/world-africa42190457.

Bhasin, T., \& Gandhi, J. (2013). Timing and targeting of state repression in authoritarian elections. Electoral Studies, 32(4), 620-631. https://doi.org/10.1016/j.electstud.2013.07.011

Biti, T. (2015). Zimbabwe: From haemorrhage to stability: A personal journey, Essays Centre for Global Development. Retrieved from: https://www.cgdev.org/publication/ft/zimbabwe-hemorrhagestability-personal-journey.

Chaturvedi, A. (2005). Rigging elections with violence. Public Choice, 125(1-2), 189-202. https://doi.org/10.1007/s11127-005-3415-6

Cheeseman, N., \& Tendi, B. M. (2010). Power-sharing in comparative perspective: the dynamics of 'unity government 'in Kenya and Zimbabwe. The Journal of Modern African Studies, 48(2), 203229. https://doi.org/10.1017/S0022278X10000224

Chigora, P., \& Guzura, T. (2011). The politics of the Government of National Unity (GNU) and power sharing in Zimbabwe: Challenges and prospects for democracy. African Journal of History and Culture, 3(2), 20-26.

Chitiyo, K., \& Kibble, S. (2014). Zimbabwe's international re-engagement. The long haul to recovery. London: The Royal Institute of International Affairs, Chatsham House.

Dziva, C., Dube, B., \& Manatsa, P. (2013). A critique of the 2008 Government of National Unity and human rights protection in Zimbabwe. International Journal of Humanities and Social Science Invention, 2(8), 83-92.

Finkeldey, J. (2011). Zimbabwe: Power-sharing as an "Impediment" for Transition or the Road to Democracy? Hamburg: University of Hamburg.

Freedom House. (2019). Zimbabwe Country report. Retrieved from: https://freedomhouse.org/report/freedom-world/2019/zimbabwe.

Hartzell, C. A., \& Hoodie, M. (2015). The Art of the Possible: Power Sharing and Post-Civil War Democracy. World Politics, 67(1), 3771. https://doi.org/10.1017/S0043887114000306 
Hoddie, M., \& Hartzell, C. (2003). Civil war settlements and the implementation of military power-sharing arrangements. Journal of Peace Research, 40(3), 303-320. https://doi.org/10.1177/0022343303040003004

Hartzell, C., \& Hoddie, M. (2003). Institutionalizing peace: power sharing and post-civil war conflict management. American Journal of Political Science, 47(2), 318-332. https://doi.org/10.1111/1540-5907.00022

Hoekman, T. (2013). Testing ties: opposition and power-sharing negotiations in Zimbabwe. Journal of Southern African Studies, 39(4), 903-920. https://doi.org/10.1080/03057070.2013.858539

Kanyinga, K., Okello, D, \& Akech. A (2010). "Contradictions of Transition to Democracy in Fragmented Societies: The Kenya 2007 General Elections in Perspective." In Tensions and Reversals in Democratic Transitions: The Kenya 2007 General Elections, edited by Karuti Kanyinga and Duncan Okello, 1-28. Nairobi: Society for International Development and the Institute for Development Studies, University of Nairobi.

Kriger, N. (2005). ZANU (PF) strategies in general elections, 1980-2000: Discourse and coercion. African Affairs, 104(414), 1-34. https://doi.org/10.1093/afraf/adi016

Laakso, L. (1999). Voting without choosing: State making and elections in Zimbabwe. Department of Political Science, University of Helsinki.

Laakso, L. (2003). Opposition politics in independent Zimbabwe. African Studies Quarterly, 7(2), 119-137.

Lijphart, A. (1977). Democracy in Plural Societies, New Haven: Yale University Press.

Lindberg, B. (2008). Fit for European Democracy?: Party Discipline in the European Parliament (Doctoral dissertation, Acta Universitatis Upsaliensis).

Mail \& Guardian. (2008). I will only support the leadership of Robert Mugabe. Retrieved: https://mg.co.za/article/2008-02-29-zimprisons-chief-orders-officers-to-vote-mugabe.

Makumbe, J. M., \& Compagnon, D. (2000). Behind the Smokescreen: The politics of Zimbabwe's 1995 general elections. University of Zimbabwe Publications Office.

Mandaza I (2011) Zimbabwe's Political Kaleidoscope: What Does 2011 Hold? Paper presented at Sapes Trust Policy Dialogue Forum: Harare: Sapes Trust.

Masunungure, E. V. (2009). Zimbabwe's Power Sharing Agreement. In a workshop on "The Consequences of Political Inclusion in Africa". Washington DC: American University.

Masunungure, E. V. (2011). Zimbabwe's militarized, electoral authoritarianism. Journal of International Affairs, 47-64.

Matlosa, K., \& Shale, V. (2013). The pains of democratisation: the uneasy interface between elections and power-sharing arrangements in Africa. Africa Review, 5(1), 1-22. https://doi.org/10.1080/09744053.2013.832064

Mehler, A. (2009). Introduction: power-sharing in Africa. Africa Spectrum, $44(3), 2-10$. https://doi.org/10.1177/000203970904400301

Mehler, A. (2009). Peace and power sharing in Africa: a not so obvious relationship. African Affairs, 108(432), 453-473. https://doi.org/10.1093/afraf/adp038

Mitchell, M. I. (2012). Power-sharing and peace in Côte d'Ivoire: past examples and future prospects. Conflict, Security \& Development, 12(2), 171-191. https://doi.org/10.1080/14678802.2012.688294

Miti, K., Abatan, E., \& Minou, S. (2013). Is Power-Sharing a Solution to Africa's Conflicts?. Southern African Peace and Security Studies, 2(1), 1-8.
Mutisi, M. (2011). Beyond the signature: Appraisal of the Zimbabwe global political agreement (GPA) and Implications for Intervention. Durban: The African Centre for the Constructive Resolution of Disputes (ACCORD).

Ndlovu-Gatsheni, S. J. (2009). Do'Zimbabweans' exist?: trajectories of nationalism, national identity formation and crisis in a postcolonial state (Vol. 3). Brussels: Peter Lang. https://doi.org/10.3726/978-3-0353-0253-0

Ndlovu-Gatsheni, S. J. (2012). Coloniality of power in development studies and the impact of global imperial designs on Africa. Australasian Review of African Studies, The, 33(2), 48. https://doi.org/10.1093/acref/9780195301731.013.49596

Ndlovu-Gatsheni, S., \& Muzondidya, J. (2011). Redemptive or Grotesque Nationalism. Rethinking Contemporary Politics in Zimbabwe. Bern: Peter Lang. https://doi.org/10.3726/978-3-0353-0107-6

Ndoma, S. (2015). MDC-T defeat in Zimbabwe: Was it only due to intimidation?. Cape Town: Afrobarometre.

Nordinger, E. A. (1972). Conflict regulation in divided societies(No. 29). Cambridge, MA: Center for International Affairs, Harvard University.

Noyes, A. (2013). Securing reform? Power sharing and civil-security relations in Kenya and Zimbabwe. African Studies Quarterly, 13(4), 27.

Penu, D.A.K, \& Vandeginste, S. (2018). Understanding governments of national unity in Africa: context, design and rationale. African Journal of Democracy and Governance , 5(4), 79-100.

Research and Advocacy Unit. (RAU), (2018). Research and Advocacy Unit (RAU). Retrieved from: http://researchandadvocacyunit.org/publication/elections.

Rich, T. (1982). Legacies of the past? The results of the 1980 election in midlands province, Zimbabwe. Africa, 52(3), 42-55. https://doi.org/10.2307/1160524

Sachikonye, L. 2011. When a state turns on its citizens: 60 years of institutionalized violence in Zimbabwe. Johannesburg: Jacana. https://doi.org/10.2307/i.ctvk3gm03

Saunders, R. (2014). Geologies of power: blood diamonds, security politics and Zimbabwe's troubled transition. Journal of Contemporary African Studies, 32(3), 378-394. https://doi.org/10.1080/02589001.2014.956501

Schedler, A., 2006a. Electoral Authoritarianism: the Dynamics of Unfree Competition. Colorado Boulder: Lynne Rienner.

Sithole, M., \& Makumbe, J. (1997). Elections in Zimbabwe: The ZANU (PF) hegemony and its incipient decline. African Journal of Political Science/Revue Africaine de Science Po

litique, 122-139.

Taylor, C. F., Pevehouse, J. C., \& Straus, S. (2017). Perils of pluralism: Electoral violence and incumbency in sub-Saharan Africa. Journal of Peace Research, 54(3), 397-411. https://doi.org/10.1177/0022343316687801

Tevera, D. S. (1989). Voting patterns in Zimbabwe's elections of 1980 and 1985. Geography, 74(2), 162-165.

Vandeginste, S. (2009). Power-sharing, conflict and transition in Burundi: twenty years of trial and error. Africa Spectrum, 44(3), 63-86. https://doi.org/10.1177/000203970904400304

Vandeginste, Stef, and Chandra Lekha Sriram. "Power sharing and transitional justice: a clash of paradigms." Global Governance 17 (2011): 489. https://doi.org/10.1163/19426720-01704006

\section{https://doi.org/10.6000/1929-4409.2021.10.124}

(c) 2021 Tirivangasi and Nyahunda; Licensee Lifescience Global.

This is an open access article licensed under the terms of the Creative Commons Attribution Non-Commercial License (http://creativecommons.org/licenses/by-nc/3.0/) which permits unrestricted, non-commercial use, distribution and reproduction in any medium, provided the work is properly cited. 